\title{
Public Debt and Low Interest Rates: Evidence from the Case of Morocco
}

http://doi.org/10.21272/fmir.4(2) 98-107.2020.

Hassane Eddassi, ORCID: https://orcid.org/0000-0002-3153-0034

$\mathrm{PhD}$, Economist/Middle Manager, Ministry of Finance, Kingdome of Morocco

\begin{abstract}
Public debt is a critical topic in modern economic literature. The necessity for massive public investments and economic reforms encouraged countries to solicit important amounts of debt from the international market. The accumulation of high levels of public debt impacts the fiscal equilibrium in countries and affects the ability of the government to meet its responsibilities. Debt Sustainability Analysis is an approach to investigate the capacity of a country to service its debt without the need to incur major fiscal costs (increasing taxes or reducing expenses). The sustainability of the debt is closely related to the interest rate and the growth rate of the GDP. It can be measured by the debt to GDP ratio. This paper investigates the debt sustainability in the case of Morocco. The paper tries to analyze the impact of the interest rate-growth rate differential on the path of the public debt in Morocco. The particularity of this analysis is the use of the Tax Adjusted Interest rate, instead of the regular interest rate. Using the adjusted rate allows for the ability to take into account the tax collected by the government on T-bills which provides a more accurate determination of the cost of the debt. The paper shows, with empirical evidence, that the sustainability of the debt can be insured when the growth rate is higher than the Tax Adjusted Interest rate, even in the absence of a balance surplus. Countries can meet their debt service requirements without severe fiscal measures under two requirements: a high growth rate and a low interest rate. The conclusions of the paper constitute a source of information for policymakers, researchers, experts, and practitioners in the field of public debt. This study provides them with the required knowledge to manage public debt, make it more sustainable, and maintain financial stability. This study can also be a starting point for researchers desiring to analyze the efficient repartition of public debt among the economic sectors to ensure strong economic growth.
\end{abstract}

Keywords: Debt Dynamic, Debt Sustainability Analysis, Fiscal Balance, Interest Rate-Growth Rate Differential, Public Debt, Stata, Tax Adjusted Interest rate, Treasury Bonds.

JEL Classification: C87, E43, E62, H63.

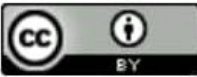

This work is licensed under a Creative Commons Attribution 4.0 International License Cite as: Eddassi, H. (2020). Public Debt and Low Interest Rates: Evidence from the Case of Morocco. Financial Markets, Institutions and Risks, 4 (2), 98-107. http://doi.org/10.21272/fmir.4(2).98-107.2020.

(C) The Author, 2020. This article is published with open access at Sumy State University.

\section{Introduction. Public Debt and Low Interest Rates: Evidence from the Case of Morocco.}

Over the years, the economic literature has debated the relationship between three indicators associated with the public debt: Interest Rate, Growth Rate, and the level of the debt to GDP. Studies attempted to analyze this relationship and provide evidence to support each claim. Especially, the literature examined the cases when the interest rates are lower than growth rates and how this could impact the path of the debt. This study is an addition to the literature as it investigates the topic of the Interest Rate-Growth Rate Differential.

The present paper aims to conduct a Debt Sustainability Analysis (DSA) for the case of Morocco. It explores the impact of interest rates on the level of the debt to GDP ratio. The main questions of the study are: does the difference between the interest rate and growth rate affect the level of the debt? Does a low interest rate (lower than growth rate) ensure debt sustainability? Empirical evidence is provided to solve the problems of the study.

The paper is divided into five sections. The first section is an introduction. The second section presents an overview of the literature related to the topics of public debt and Interest Rate-Growth Rate Differential. Section three explores the data used to analyze the research problem. Section four describes the results of the analysis and the last section, section five, is a conclusion of the paper. 
Financial Markets, Institutions and Risks, Volume 4, Issue 2, 2020 ISSN (online) - 2521-1242 ISSN (print) - 2521-1250

It is worth mentioning that this paper is based on the works of Blanchard Olivier (Blanchard, 2019) and Feenberg et al (Feenberg, Tepper, \& Welch, 2018).

\section{Literature review}

For years, economists have studied the link between debt and economic growth. Many opinions were presented in this regard, and experts are divided between supporters and opponents of public debt.

According to debt advocates, there is a positive relationship between public debt and economic growth, and debt is indispensable to ensure economic recovery since it boosts investment (Clements \& Bhattacharya, 2014). Empirical evidence shows an improvement of economic growth when the ratio of debt to GDP is less than $51 \%$, and when the debt exceeds this ratio, it becomes an obstacle (Jérôme, 2012). Another study found this ratio to be around 90\% for some European countries (Checherita-Westphal \& Rother, 2011). The level of this threshold depends on the amount of debt directed towards financing productive public capital (Aschauer, 2000).

On the other hand, many economists are convinced that debt has negative effects, increases future taxes, and weakens the impact of economic growth. Some early literature from the previous century argued that debt is a burden for future generations as it lowers the flow of national income (Modigliani, 1961). (Krugman, 1988) states that a high public debt dissuades the private sector to invest in the country because they predict a large risk of default. In addition, the anticipation of an increase in future taxes, due to high debt, may lead the private sector to lower investments (Oks \& van Wijnbergen, 1995).

To assess the effect of debt on economic growth, economists apply the concept of Debt Sustainability. While this approach is widely accepted by experts, they are still divided over the indicators to consider and the ratios to take into account to assess the sustainability of the public debt.

The debt sustainability is defined as the capacity of a country to meet its future debt service without the need to incur major fiscal costs (increasing taxes or reducing public expenditures). "A country's debt is said to be sustainable if the present value of resource transfers to nonresidents is equal to the value of the initial debt owed to them; that is, the intertemporal budget constraint holds" (Bank W. , 2005).

One of the well-known tools used to assess the sustainability of public debt is the Debt Sustainability Analysis (DSA) tool developed by the IMF and the World Bank. This tool allows policymakers and experts of the IMF and World Bank to assess the level of the debt in low and middle-income countries while preventing the accumulation of public debt to critical levels (Bank T. W., 2018).

The DSA framework has many advantages. Its annual frequency improves the efficiency of the reports and the fiscal advice to countries (BANK, 2012). In addition, the tool provides information to countries and creditors, produces cross country information, enhances transparency, and has a satisfactory track record (Mustapha, 2015).

On the other hand, some analysts consider the framework to be mainly interested in the repayability of the debt at the expense of the sustainable development of the country (Oddone, 2005). It is argued that the IMF has no consideration for the human rights and the basic needs of the population (Gunter, 2009). In addition, basing the DSA results on historical data to forecast the future can be misleading especially in the case of unstable countries (Nissanke, 2013). Besides, the results of the analysis are only valid with respect to the underlying scenarios (Wyplosz, 2007). Moreover, the framework investigates only government external debt and ignores both government internal debt and private external debt (Panizza, 2008). Furthermore, a conflict of interest may arise since the IMF is both the lender and the provider of the reports (Riegner, 2014).

Besides the IMF's DSA, many economists use other techniques to assess the sustainability of the debt, and "since the issue of external debt sustainability is a broad concept and includes a large number of indicators, the topic of debt sustainability can be interpreted differently in each paper. It depends on the author's approach and specific research questions" (Kazakova \& Inaba, 2018).

A report by the United Nations Institute for Training and Research (UNITAR, 2006) summarizes the different approaches to assess the sustainability of the debt. One is the comparison of the Present Value of the primary surplus with the Present Value of debt interest payments. Another approach is the comparison between Present Discounted Value (PDV) of current and future primary expenditure with PDV of current and future incomes (the concept of solvency). An indicator analyses the Present Value of interest payments and the Present Value of primary surpluses. In addition, a different method compares the fiscal revenues with the debt service. 
As we can notice, many approaches and methods are applied to assess the sustainability of the debt, but this paper adopts a different methodology which is the comparison of the interest rate and the rate of growth of the economy or the Interest Rate-Growth Rate Differential. This approach stipulates that the interest rate incurred by the debt should not be higher than the rate of growth of the economy (Terry \& Maana, 2014). When the interest rate is higher than the growth of GDP, the debt to GDP ratio will rise (Reddy, 2006). It is then obvious that "The difference between the average interest rate that governments pay on their debt and the nominal growth rate of the economy is a key variable for debt dynamics and sovereign sustainability analysis" (Westphal, 2019). For this reason, we can say that the cost of the debt in a country will heavily depend on the gap between the interest rate and the growth rate (Mehrotra, 2017).

The Interest Rate-Growth Rate Differential is a key concept to assess the sustainability of public debt. In this paper, we will apply this concept to the case of Morocco to investigate the path of the public debt in the future and observe if this concept holds for Morocco. The next section examines the data used for the study.

\section{Data}

As previously mentioned, the paper investigates the relationship between the interest rate and the growth rate in the case of Morocco, and whether it influences the level of the debt.

Concerning the growth rate, we will be using the rate of the evolution of the GDP from 1996 to 2018. For the interest rate, we will explore the nominal rate paid for Treasury Bills (designed as T-Bills onward) for two periods: 1 year and 10 years. The following table presents the data for Morocco from 1996 to 2018:

Table 1. Interest Rate and Growth Rate

\begin{tabular}{|l|c|c|c|}
\hline \multicolumn{1}{|c|}{ Year } & Growth rate & 10 years T-bill rate & 1 year T-bill rate \\
\hline $\mathbf{1 9 9 6}$ & 12.4 & 10.3 & 7 \\
\hline $\mathbf{1 9 9 7}$ & -1.6 & 9 & 6.8 \\
\hline $\mathbf{1 9 9 8}$ & 7.2 & 8 & 6 \\
\hline $\mathbf{1 9 9 9}$ & 1.1 & 7.5 & 5 \\
\hline $\mathbf{2 0 0 0}$ & 1.9 & 6.8 & 3 \\
\hline $\mathbf{2 0 0 1}$ & 7.3 & 6.8 & 3.2 \\
\hline $\mathbf{2 0 0 2}$ & 3.1 & 5.8 & 2.8 \\
\hline $\mathbf{2 0 0 3}$ & 6 & 5.5 & 2.8 \\
\hline $\mathbf{2 0 0 4}$ & 4.8 & 4.9 & 3 \\
\hline $\mathbf{2 0 0 5}$ & 3.3 & 4.8 & 3.1 \\
\hline $\mathbf{2 0 0 6}$ & 7.6 & 3.3 & 3.9 \\
\hline $\mathbf{2 0 0 7}$ & 3.5 & 3.4 & 3.5 \\
\hline $\mathbf{2 0 0 8}$ & 5.9 & 3.8 & 3.1 \\
\hline $\mathbf{2 0 0 9}$ & 4.2 & 4 & 3.1 \\
\hline $\mathbf{2 0 1 0}$ & 3.8 & 4.1 & 3 \\
\hline $\mathbf{2 0 1 1}$ & 5.2 & 4.1 & 3.1 \\
\hline $\mathbf{2 0 1 2}$ & 3 & 4.5 & 3 \\
\hline $\mathbf{2 0 1 3}$ & 4.5 & 5.5 & 2.5 \\
\hline $\mathbf{2 0 1 4}$ & 2.7 & 4.5 & 2 \\
\hline $\mathbf{2 0 1 5}$ & 4.5 & 3.5 & 2.8 \\
\hline $\mathbf{2 0 1 6}$ & 1.1 & 3.1 & \\
\hline $\mathbf{2 0 1 7}$ & 4.2 & 3.2 & \\
\hline $\mathbf{2 0 1 8}$ & 3 & 3.4 & \\
\hline
\end{tabular}

Source: Central bank of Morocco; World Bank.

The table below presents a summary of the data 
Table 2. Data Summary

\begin{tabular}{r|rrrrr} 
Variable & Obs & Mean & Std. Dev. & Min & Max \\
\hline year & 23 & 2007 & 6.78233 & 1996 & 2018 \\
r10y & 23 & 5.208696 & 1.996341 & 3.1 & 10.3 \\
g & 23 & 4.291304 & 2.786642 & -1.6 & 12.4 \\
rg & 0 & & & & \\
r1y & 23 & 3.782609 & 1.509862 & 2 & 7 \\
\hline maturity & 0 & & & & \\
tax_1y & 23 & 22.17391 & 4.217412 & 20 & 30 \\
tax_10y & 23 & 22.17391 & 4.217412 & 20 & 30 \\
no_tax_hol s & 23 & 20 & 0 & 20 & 20 \\
alpha & 23 & .5 & 0 & .5 & .5 \\
\hline r & 23 & 4.495652 & 1.713444 & 2.55 & 8.65 \\
tau & 23 & .2 & 0 & .2 & .2 \\
beta & 23 & .8 & 0 & .8 & .8 \\
r_adj & 23 & 3.649565 & 1.216024 & 2.142 & 6.574
\end{tabular}

Source: STATA generated table.

Figures 1 and 2 display the comparison of the growth rate with the 10 years and 1 year T-bills respectively.

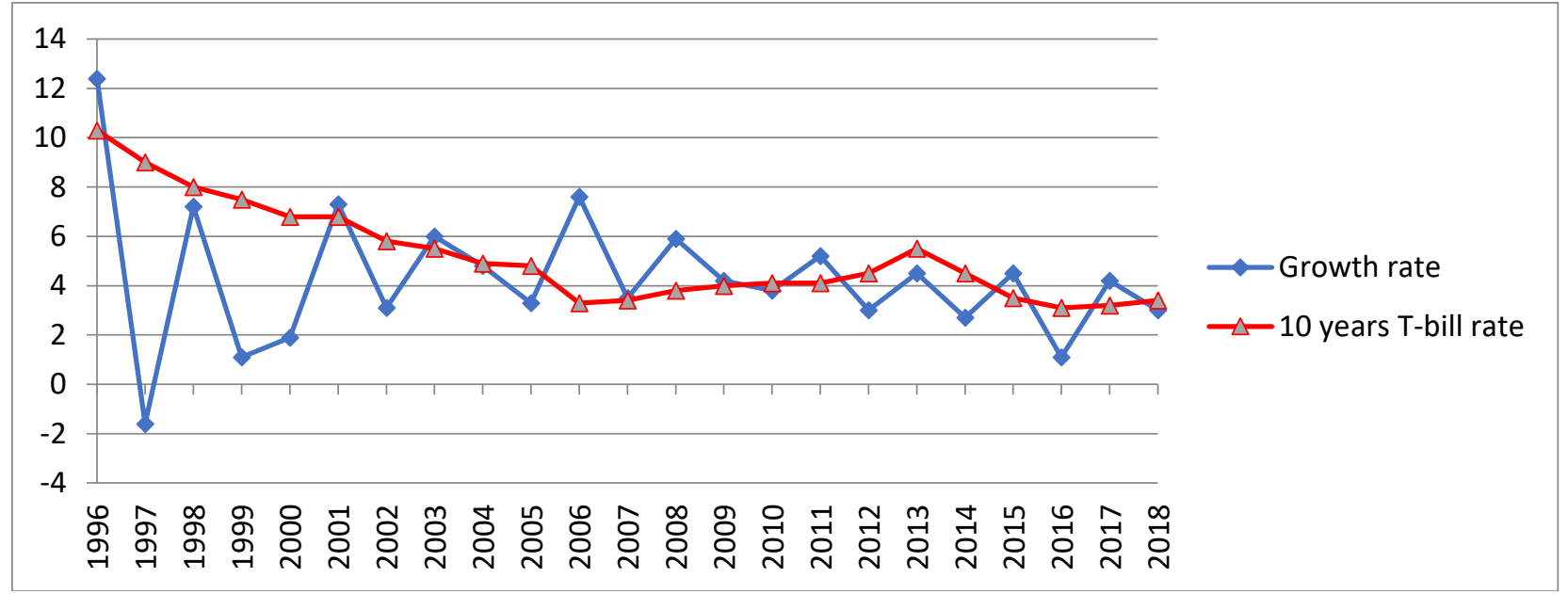

Figure 1. Nominal GDP Growth Rate and 10 Years T-bill Rate. 1996-2018

Source: Data from Table 1.

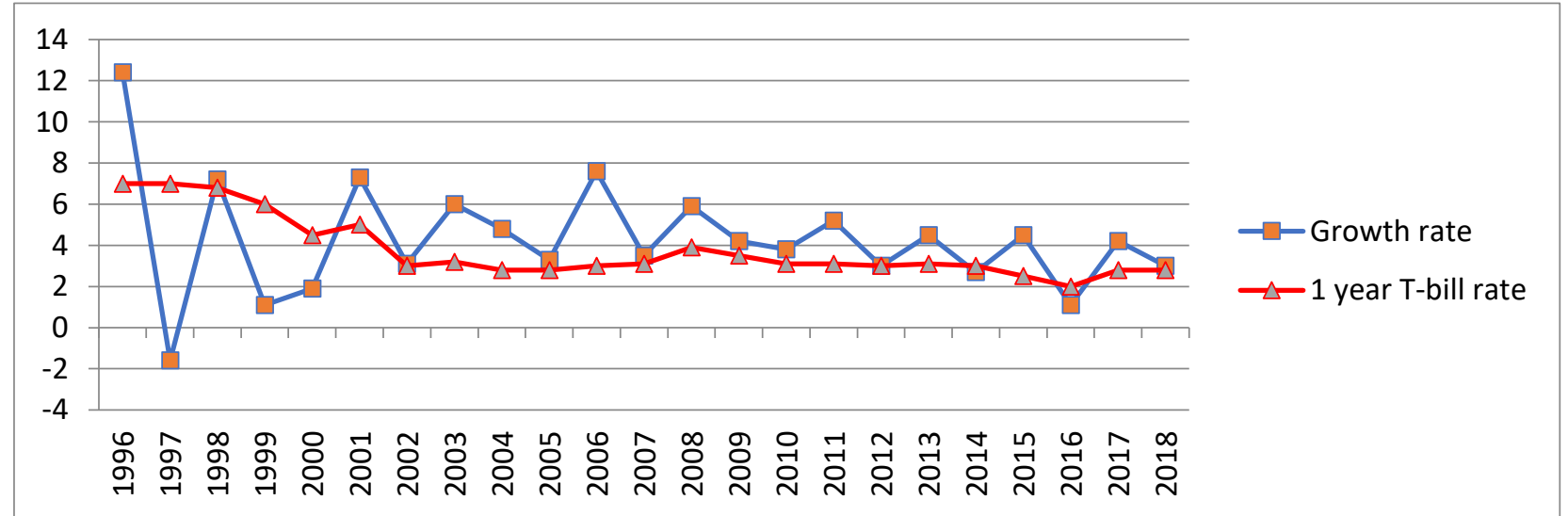

Figure 2. Nominal GDP Growth Rate and 1 Year T-bill Rate. 1996-2018

Source: Data from Table 1.

From the figures, we can derive the following observations:

The evolution of the GDP growth rate in Morocco is not constant. This can be explained by the multiple internal and external events affecting the economy. Over the studied period, the growth rate averaged $4.30 \%$.

$>\quad$ Interest rates on both 1 year and 10 years T-bills have declined during the period 1996-2018. Many explanations can be given. First, the robustness of the Moroccan economy reduced the risks of default pushing the 
rates to decline. Second, during this period, the demand for Moroccan T-bills increased driving the rates to go down. Finally, and after the financial crisis of 2008, the world tendency was towards lower interest rates.

Concerning 1 year T-bills interest rate, and starting from 2001, the growth rate was higher than the interest rate, except in 2016.

For the 10 years T-bills, the growth rate was higher than the interest rate only during the period 2006-2011. For the rest of the period, we can notice the opposite tendency.

The data above consider the interest rate to be the total cost of the debt, but, according to Blanchard, "Many, but not all, holders of government bonds pay taxes on the interest paid, so the interest cost of debt is actually lower than the interest rate itself' (Blanchard, 2019). Taking into consideration the taxation of T-Bills, the interest paid in reality is lower than the previously mentioned interest rate. In order to get the real cost of the public debt, we should construct a series for the relevant interest rate by taking into account the tax paid and also the proportion of the exempted taxpayers.

To compute the average tax rate for every year, depending on the maturity of the debt (1 year or 10 years), we use the following equation:

$$
\tau_{t}=\alpha_{t} \times \tau_{1, t}+\left(1-\alpha_{t}\right) \times \tau_{10, t} .
$$

Where:

$\tau_{t} \quad$ The average tax rate for year $\mathrm{t}$

$\tau_{1, t} \quad$ The tax rate for 1 year T-bill.

$\tau_{10, t}$ The tax rate for 10 years T-bill.

$\alpha_{t} \quad$ (10-average maturity)/9 with average maturity is 5.5 years.

In addition, not all bondholders pay the tax on the interest. In fact, only individuals pay this tax while corporations and foreign investors are exempted. This factor should be taken into account to calculate only the portion of the tax paid. The proportion of taxpayers subject to taxation is designed by $\beta_{t}$, then, the adjusted interest rate (taking into account the average tax rate and population subject to tax) is computed using the following formula:

$$
i_{\text {adj,t }}=i_{t}\left(1-\tau_{t} \times \beta_{t}\right)
$$

This method provides an adjusted interest rate which is considered as the real cost of the debt. The next section applies the adjusted interest rate to present the results of the analysis.

\section{Results}

The result of equation 2 is presented in table 3, and plotted in figures 3 and 4.

Table 3. The Adjusted Interest Rate on Moroccan T-bills (1 and 10 years)

\begin{tabular}{|l|c|c|c|c|}
\hline \multicolumn{1}{|c|}{ Year } & Growth Rate & 10 Years T-bill Rate & 1 Year T-bill Rate & Adjusted Rate \\
\hline $\mathbf{1 9 9 6}$ & 12.4 & 10.3 & 7 & 6.6 \\
\hline $\mathbf{1 9 9 7}$ & -1.6 & 9 & 7 & 6.1 \\
\hline $\mathbf{1 9 9 8}$ & 7.2 & 8 & 6.8 & 5.6 \\
\hline $\mathbf{1 9 9 9}$ & 1.1 & 7.5 & 6 & 5.1 \\
\hline $\mathbf{2 0 0 0}$ & 1.9 & 6.8 & 4.5 & 4.3 \\
\hline $\mathbf{2 0 0 1}$ & 7.3 & 6.8 & 5 & 5,0 \\
\hline $\mathbf{2 0 0 2}$ & 3.1 & 5.8 & 3 & 3.7 \\
\hline $\mathbf{2 0 0 3}$ & 6 & 5.5 & 3.2 & 3.7 \\
\hline $\mathbf{2 0 0 4}$ & 4.8 & 4.9 & 2.8 & 3.2 \\
\hline $\mathbf{2 0 0 5}$ & 3.3 & 4.8 & 2.8 & 3.2 \\
\hline $\mathbf{2 0 0 6}$ & 7.6 & 3.3 & 3 & 2.6 \\
\hline
\end{tabular}


Table 3 (cont.). The Adjusted Interest Rate on Moroccan T-bills (1 and 10 years)

\begin{tabular}{|l|c|c|c|c|}
\hline $\mathbf{2 0 0 8}$ & 5.9 & 3.8 & 3.9 & 3.2 \\
\hline $\mathbf{2 0 0 9}$ & 4.2 & 4 & 3.5 & 3.2 \\
\hline $\mathbf{2 0 1 0}$ & 3.8 & 4.1 & 3.1 & 3,0 \\
\hline $\mathbf{2 0 1 1}$ & 5.2 & 4.1 & 3.1 & 3,0 \\
\hline $\mathbf{2 0 1 2}$ & 3 & 4.5 & 3 & 3.2 \\
\hline $\mathbf{2 0 1 3}$ & 4.5 & 5.5 & 3.1 & 3.6 \\
\hline $\mathbf{2 0 1 4}$ & 2.7 & 4.5 & 2.5 & 3.2 \\
\hline $\mathbf{2 0 1 5}$ & 4.5 & 3.5 & 2 & 2.5 \\
\hline $\mathbf{2 0 1 6}$ & 1.1 & 3.1 & 2.8 & 2.1 \\
\hline $\mathbf{2 0 1 7}$ & 4.2 & 3.2 & 2.8 & 2.5 \\
\hline $\mathbf{2 0 1 8}$ & 3 & 3.4 & & 2.6 \\
\hline
\end{tabular}

The adjusted $R$ is calculated using the equation $i_{t}\left(1-T_{t} X \beta_{t}\right)$.

Source: Equation (2).

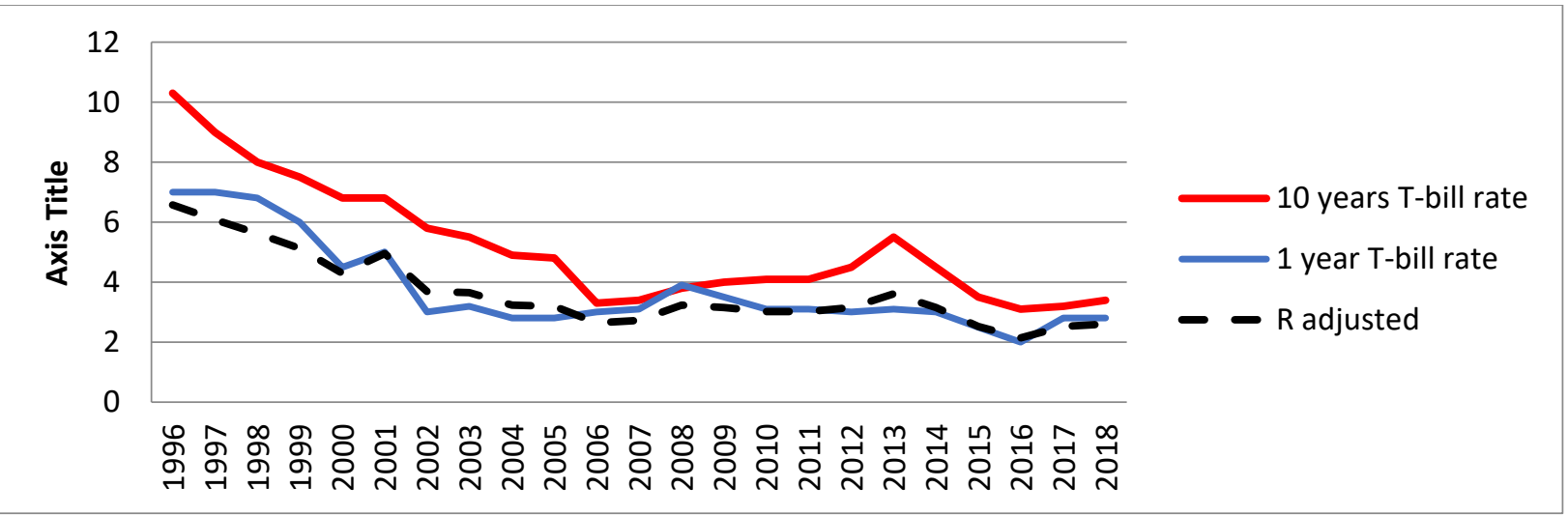

Source: Data from Table 3.

Figure 3. 1 Year Rate, 10 Years Rate, and Adjusted Rate. 1996-2018

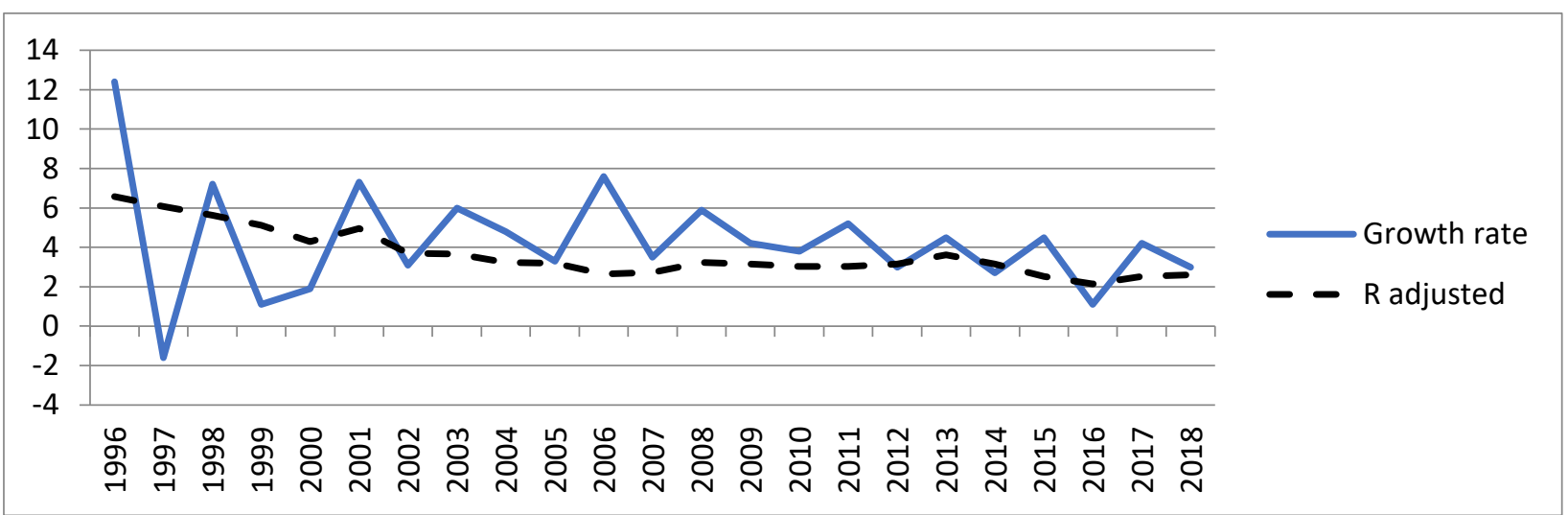

Source: Data from Table 3.

Figure 4. Nominal GDP Growth Rate and Adjusted Rate. 1996-2018

We can cite the following observations:

- $\quad$ The adjusted interest rate is always below the 10 years rate. This can be explained by the fact that the adjusted rate takes into account the tax collected by the government, which reduces the cost of the debt.

- $\quad$ Compared to the 1-year rate, the adjusted rate is lower for most of the studied period. Only for the periods 2002-2005 and 2012-2014 that the adjusted rate is higher.

- $\quad$ The growth rate was higher than the adjusted rate during most of this period, except for years 1997, 1999, 2000, 2002, 2012, 2014 and 2016.

In this stage of the study, and as we generated the Adjusted Rate on the Treasury bonds, we can determine how the debt will evolve over the years. To predict the level of the debt, we use the following equation: 


$$
d_{t+n}=\left(\prod_{i=1}^{n} \frac{1+r_{a d j, t+i}}{1+g_{t+i}}\right) d_{t}
$$

Where $d_{t}$ is the debt to GDP ratio in year $t$ and $d_{t+n}$ is the level in year $t+n$. This equation assumes a primary balance which is always equal to 0 (Blanchard, 2019).

Using Stata software, we generate figures 5 and 6 which show the dynamics of the Moroccan debt for the coming years. The figures demonstrate the path of the debt starting at different dates in the past. Figure 5 is plotted using the Non-Tax Adjusted Interest Rate, while figure 6 uses the Tax Adjusted Interest Rate. It is worth mentioning that the ratio of the debt to GDP is normalized to $100 \%$ in each starting period.

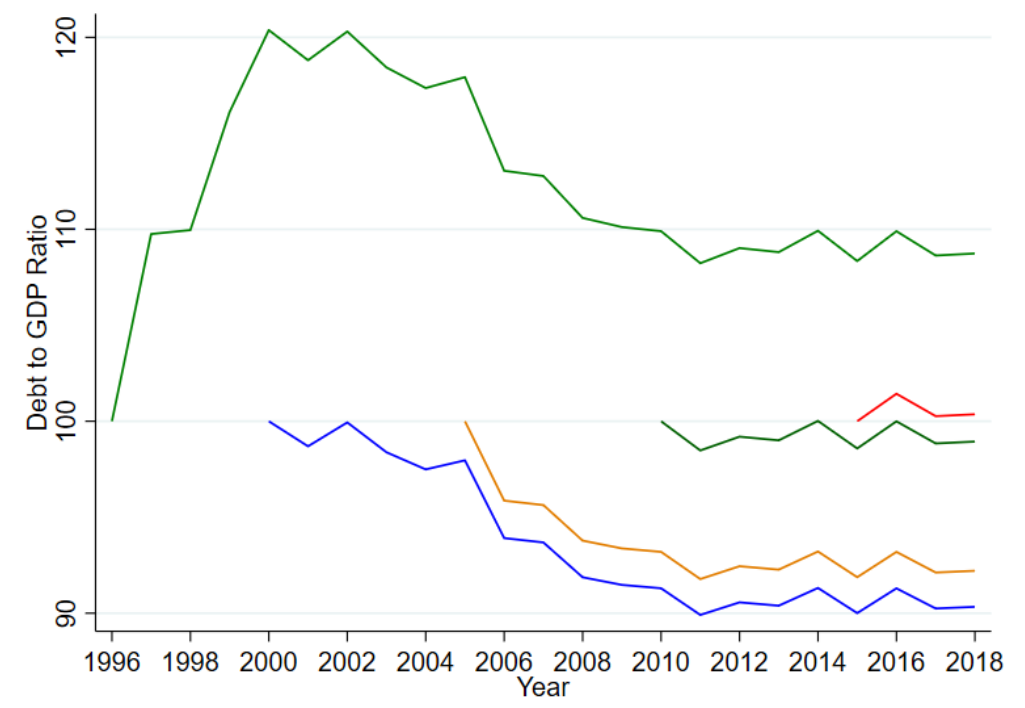

Figure 5. Debt Dynamics, with Zero Primary Balance, starting in Year t, using the Non-Tax Adjusted Rate Source: STATA generated graph.

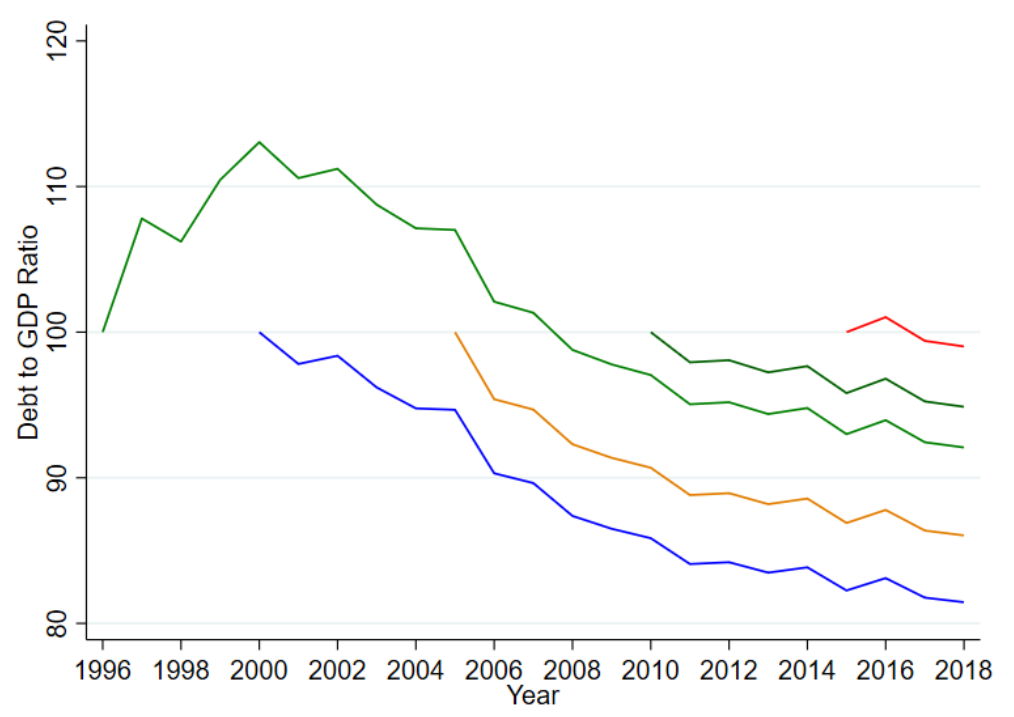

Figure 6. Debt Dynamics, with Zero Primary Balance, starting in Year t, using the Tax Adjusted Rate

Source: STATA generated graph.

Figure 5 shows the evolution of the debt in the case of Morocco, taking into account the Non-Tax Adjusted Interest Rate. As it can be seen, when the year 1996 is set as a starting period, the debt will increase to reach a level of $120 \%$ of GDP and then will decrease to less than $110 \%$ in 2018. For the other starting years (2000, 
$2005,2010,2015)$, the debt will always decrease under the $100 \%$ level and in the long run will stabilize at a rate of $90 \%$. We can notice that during the periods when the growth rate was higher than the interest rate, the ratio of debt to GDP was decreasing. Conversely, when the growth rate was below the interest rate (starting 1996), the debt increased substantially.

In figure 6, which is applying the Tax Adjusted Interest Rate, the level of the debt is lower than the levels shown in figure 5 . The reason is that the cost of the debt is reduced by the amount of the tax, making the debt less expensive. Starting from 1996, the debt increases above 110\% of GDP (versus 120\% in figure 5), and then starts to decrease to a level close to $90 \%$. For the other starting periods, the level of the debt to GDP decreased and reached a level close to $80 \%$ (compared to $90 \%$ in the previous figure). As mentioned in figure 5, this pattern is explained by the growth rate-interest rate differential. For the periods when the growth rate is higher than the interest rate, the debt is decreasing over time and becomes sustainable.

\section{Conclusion}

At the beginning of this paper, the main question was whether a low interest rate can sustain public debt in Morocco. The study presented empirical evidence that showed a close relationship between the interest rategrowth rate differential and the path of the debt.

In fact, for the period when the growth rate was higher than the interest rate, the public debt recorded a declining path, meaning that it can be sustained in the long run even without a surplus balance. Furthermore, this study shows that an interest rate higher than the growth rate will contribute to an increase of the debt making it unsustainable. This situation will necessitate severe fiscal interventions in the form of an increase in taxes and implementation of austerity measures.

As a conclusion, the paper confirms that, even in the absence of a primary balance surplus, the public debt can be sustained over time if the growth rate of the GDP is higher than the interest rate on public debt. It is proved, with evidence, that a low interest rate combined with strong growth of the economy can achieve the sustainability of the debt and prevent the accumulation of high levels of debt. This is clearly showed in the graphs below:

Nominal GDP Growth Rate and Adjusted Rate. 1996-2018.

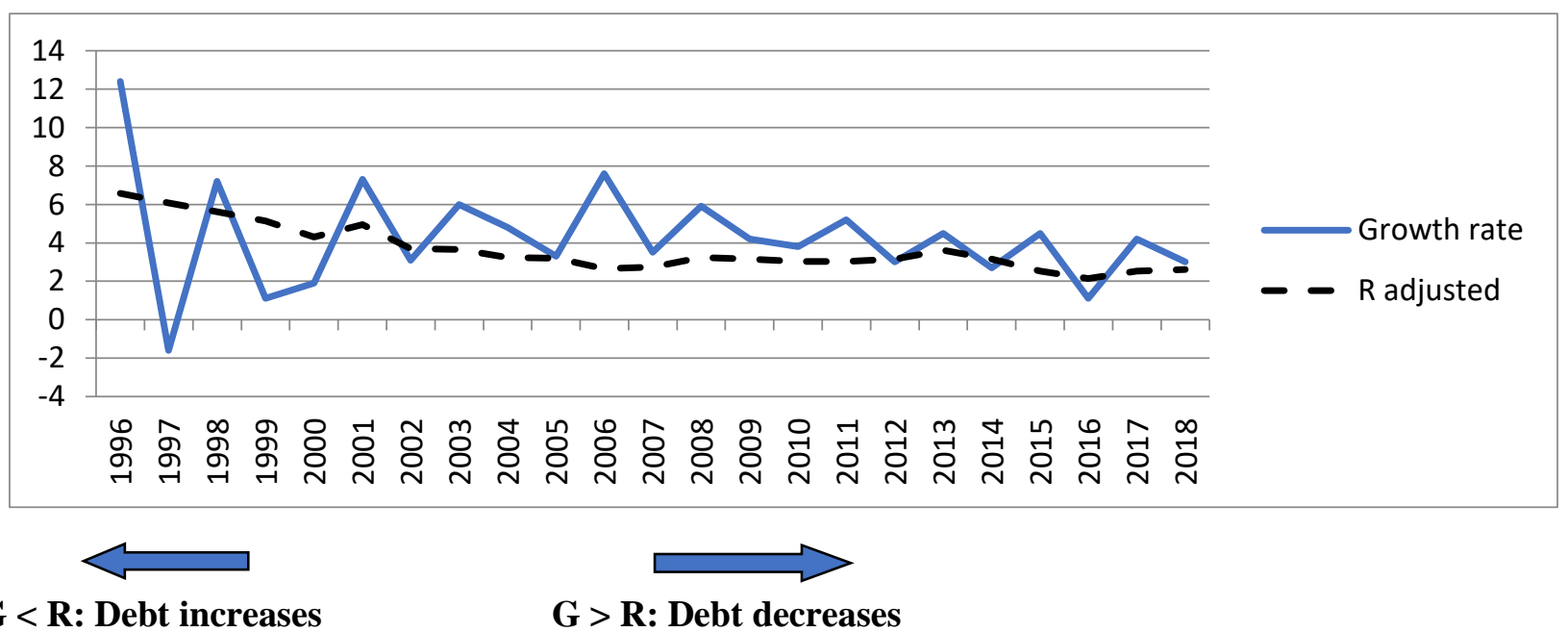

\section{G < R: Debt increases}

G > R: Debt decreases

Figure 7. Nominal GDP Growth Rate and Adjusted Rate. 1996-2018

Source: Data from Table 3.

Debt Dynamics, with Zero Primary Balance, starting in Year t, using the Tax Adjusted Rate 


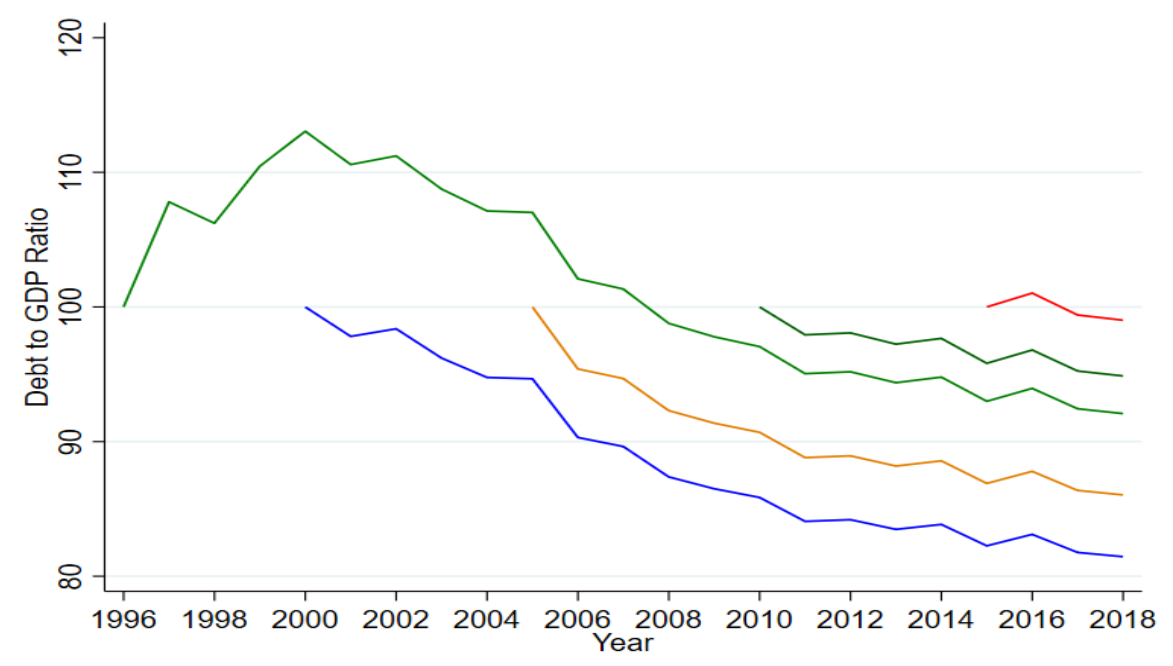

Figure 8. Debt Dynamics, with Zero Primary Balance, starting in Year t, using the Tax Adjusted Rate

Source: Data from Table 3.

In these periods of low interest rates, the public debt can be sustained without the need to incur fiscal costs (increasing taxes or reducing expenditures) as long as the growth rate is high. The sustainability of the debt requires efficient financing of profitable investments to ensure high levels of growth rate. This will need further investigation and can be a topic of future studies to understand how to distribute the public debt among the different sectors of the economy in order to achieve a high growth of GDP.

\section{References}

1. Aschauer, D. A. (2000, 2). Do states optimize? Public capital and economic growth. The Annals of Regional Science volume , 343-363. Retrieved from: https://ideas.repec.org/a/spr/anresc/v34y2000i3p343363.html

2. BANK, I. M. (2012). Revisiting the Debt Sustainability Framework for Low-Income Countries. Retrieved from: https://www.imf.org/external/np/pp/eng/2012/011212.pdf

3. $\quad$ Bank, T. W. (2018). Debt Sustainability Analysis (DSA). Retrieved 04 2020, from The World Bank. Retrieved from: https://www.worldbank.org/en/topic/debt/brief/dsa

4. Bank, W. (2005). Fiscal Sustainability in Theory and Practice. World Bank Publications. Retrieved from: https://openknowledge.worldbank.org/handle/10986/7495

5. $\quad$ Blanchard, O. (2019, April). Public Debt and Low Interest Rates. American Economic Review , 11971229. Retrieved from: https://pubs.aeaweb.org/doi/pdfplus/10.1257/aer.109.4.1197

6. Checherita-Westphal, C. (2019). Interest rate-growth differential and government debt dynamics. ECB Economic Bulletin . European Central Retrieved from: Bank.https://www.ecb.europa.eu/pub/economic bulletin/focus/2019/html/ecb.ebbox201902_06 0c96ee6f7c.en.html

7. Checherita-Westphal, C., \& Rother, P. (2011, 6). The Impact of Government Debt on Growth. An Empirical Investigation for the Euro Area. Revue économique, 1015-1029. Retrieved from: https://www.cairn.info/revue-economique-2011-6-page-1015.htm

8. Clements, B., \& Bhattacharya, R. $(2014,12)$. Quels sont les bienfaits de l'allégement de la dette? Finances \& Développement. Retrieved from: https://www.imf.org/external/pubs/ ft/fandd/fre/2004/ 12/pdf/bhattach.pdf

9. Feenberg, D., Tepper, C., \& Welch, I. (2018, january ). Are Interest Rates Really Low? National Bureau of Economic Research. Retrieved from: https://ideas.repec.org/p/nbr/nberwo/24258.html

10. Gunter, B. G. (2009). Towards an MDG-Consistent Debt Sustainability Concept. International Policy Centre for Inclusive Growth. Retrieved from: https://ideas.repec.org/p/ipc/opager/87.html

11. Jérôme, O. (2012). Dette extérieure et qualité des institutions, impact sur la croissance économique : cas de l'UEMOA. Paris: ENSEA. Retrieved from: https://www.uneca.org/sites/default/files/uploadeddocuments/AEC/2013/ dette_extrieure_et_qualit_des_institutions_impact_sur_la_croissance_conomique_ cas_de_1_uemoa.pdf 
12. Kazakova, S., \& Inaba, K. $(2018,11)$. Debt Sustainability in the Developing Countries : Case Study of the Kyrgyz Republic. The Ritsumeikan Economic Review, 438-453. Retrieved from: https://www.semanticscholar.org/paper/Debt-Sustainability-in-the-Developing-Countries-\%3A-KazakovaInaba/4b8928c11f349cebe16a260bbfafaf0e32b99113

13. Krugman, P. (1988). Financing vs. forgiving a debt overhang. Journal of Development Economics , 253-268. Retrieved from: https://www.sciencedirect.com/science/article/abs/pii/0304387888900442

14. Mehrotra, N. R. (2017). Debt Sustainability in a Low Interest Rate World. Hutchins Center Working Papers. Hutchins Center on Fiscal and Monetary Policy. Retrieved from: https://www.brookings.edu/wpcontent/uploads/2017/06/wp32 mehrotra debtsustainability.pdf

15. Modigliani, F. (1961). Long-run implications of alternative fiscal policies and the burden of the national debt. Economic Journal, 730-755. Retrieved from: https://academic.oup.com/ej/articleabstract/71/284/730/5250136

16. Mustapha, S. (2015). What does the latest literature say on the strengths and weaknesses of the IMF's Debt Sustainability Analysis? Overseas Development Institute. Retrieved from: https://assets.publishing.service.gov.uk/media/57 a08999ed915d622c0002d5/What_ does_the_latest _literature_say_on_the_strengths_and_weaknesses_of_the_IMFs_Debt_Sustainability_Analysis.pdf

17. Nissanke, M. (2013). Managing Sovereign Debt for Economic Development in Africa - A Critical Appraisal of the Joint Bank-Fund Debt Sustainability Framework and Its Implications for Sovereign Debt Management. London: School of Oriental and African Studies. Retrieved from: https://www.cigionline.org/sites/default/files/ documents/PB\%20no.133_0.pdf

18. Oddone, F. (2005). Still Missing the Point: Unpacking the new World Bank/IMF debt sustainability framework. EURODAD. Retrieved from: https://eurodad.org/uploadedfiles/whats_new/reports/eurodad $\% 20 \mathrm{wb} \%$ 20and \%20imf\% 20still\%20missing\%20the\%20point.pdf

19. Oks, D., \& van Wijnbergen, S. (1995). Mexico after the debt crisis: is growth sustainable? Journal of Development Economics, 155-178. Retrieved from: https://econpapers.repec.org/article/eeedeveco/ v_3a47_3ay_3a1995_3ai_3a1_3ap_3a155-178.htm

20. Ouedraogo, J. (2012). Dette extérieure et qualité des institutions, impact sur la croissance économique : cas de l'UEMOA. ENSEA. Retrieved from: https://www.uneca.org/sites/default/files/uploadeddocuments/AEC/2013/dette_extrieure_et_qualit_des_institutions_ impact_sur_la_croissance_ conomique_cas_ de_1_uemoa.pdf

21. Panizza, U. (2008). Domestic and External Public Debt in Developing Countries . Un. Retrieved from: https://debt-and-finance.unctad.org/Documents/Discussion-papers/Domestic_and_External_Public_Debt_in_ Developing Countries_PANIZZA_2008.pdf

22. Reddy, M. (2006). Assessing Sustainability of Fiji’s Public Debt: A Cointegration Analysis Approach. Economic Association of Fiji. Retrieved from: http://www.rbf.gov.fj/docs/Spch\%20by\%20Dr\% 20Mahendra\%20Reddy\% 20at\%20Eco\%20Assoc\%20Forum\%20RBF_01mar06.pdf

23. Riegner, M. (2014). Legal Frameworks and General Principles for Indicators in Sovereign Debt Restructuring. UNCTAD. Retrieved from: https://cpb-us-w2.wpmucdn.com/campuspress.yaleedu/ dist/8/1581/files/2016/10/I-Riegner-Special-Edition-2m1p10b.pdf

24. Terry, R., \& Maana, I. (2014). An Assessment of Kenya's Public Debt Dynamics and Sustainability. Retrieved from: https://www.semanticscholar.org/paper/An-Assessment-of-Kenya-\%E2\%80\%99-s-PublicDebt-Dynamics-and-Ryan-Maana/739a3b6cce03db94dc9032f22bb4eb489af76b0e

25. Westphal, C. C. (2019). Interest rate-growth differential and government debt dynamics. ECB Economic Bulletin. European Central Bank. Retrieved from: https://www.ecb.europa.eu/pub/economicbulletin/focus/2019/ html/ecb.ebbox201902_06 0c96ee6f7c.en.html

26. Wyplosz, C. (2007). Debt Sustainability Assessment: The IMF Approach and Alternatives. Geneva: Graduate Institute of International Studies. Retrieved from: https://ideas.repec.org/p/gii/giihei/heiwp032007.html 